\title{
Wpływ wielkości kapitału banku na współczynnik wypłacalności
}

\section{Wstęp}

Współczynnik wypłacalności jest to relacja pomiędzy kapitałem banku a jego aktywami bilansowymi oraz pozycjami bilansowymi, którym przyporządkowano określone wagi ryzyka. Wyliczony zgodnie z powyższą regułą iloraz powinien być nie mniejszy niż $8 \%$. Wielkość ta została ustalona w sposób empiryczny, zatem nie gwarantuje automatycznie bezpieczeństwa prowadzenia działalności przez bank oraz jego wypłacalności w długim okresie [Zaleska 1999, s. 71]. W historii odnotowano wiele przypadków, kiedy to dochodziło do bankructw banków mimo utrzymywania wymaganego poziomu współczynnika wypłacalności.

Obecnie zdecydowana większość banków utrzymuje współczynnik wypłacalności na poziomie powyżej wymaganych $8 \%$, co oznacza, że posiadają one nie tylko kapitał na pokrycie ponoszonego aktualnie ryzyka, ale też nadwyżkę pozwalającą na pokrycie wyższego ryzyka, na które mogą być narażone $\mathrm{z}$ tytułu rozszerzania działalności kredytowej lub niekorzystnych zmian warunków zewnętrznych [Raport o stabilności... 2003, s. 133].

Znaczna nadwyżka współczynnika wypłacalności ponad jego minimalny poziom określony wymaganiami nadzorczymi wskazuje na niepełne wykorzystanie możliwości ekspansji kredytowej banku. Rozszerzanie skali działalności i osiąganie dodatkowych zysków w bankach utrzymujących współczynnik wypłacalności znacznie powyżej obowiązujących wymogów mogłoby się odbywać bez naruszania granic ryzyka wypłacalności. Gdyby jednak współczynnik wypłacalności obniżył się poniżej wymaganych $8 \%, 12 \%$ lub 15\% (wymagane minimum wynosi $15 \%$ w pierwszym roku działania banku, $12 \%$ w drugim i $8 \%$ w kolejnych latach) w przypadku wystąpienia strat działalność banku zostałaby obarczona nadmiernym ryzykiem niewypłacalności [Bień, Sokół 2000, s. 83-84]. 


\section{Wielkość banku a wysokość współczynníka wypłacalności}

Wiele banków w krajach Europy Zachodniej i w Stanach Zjednoczonych utrzymuje kapitał na poziomie znacznie przekraczajacym minimalne wymogi określone przez władze nadzorcze. Uzasadnieniem tego może być fakt, że banki, chcąc aktywnie uczestniczyć w rynku kapitałowym i pozyskać zaufanie nabywców emitowanych przez siebie instrumentów finansowych, muszą legitymować się ratingiem kredytowym powyżej pewnego poziomu. Dlatego też niektóre $\mathrm{z}$ banków mogą dążyć do utrzymywania wyższego poziomu kapitału w celu uzyskania wyższej oceny wiarygodności kredytowej. Innym wyjaśnieniem na utrzymywanie znacznej nadwyżki kapitału przez instytucje kredytowe może być fakt, że niektóre banki uwzględniają cykliczność rozwoju gospodarczego w planowaniu finansowym, a utrzymywana przez nie nadwyżka ma na celu pokrycie nieobsługiwanych w terminie kredytów, których udział wzrasta w przypadku wystapienia kryzysu gospodarczego [Richardson, Stephenson 2000 , s. 43-44]. Powodem utrzymywania przez banki nadwyżek kapitału powyżej ustalonego minimum może być też dążenie do uniknięcia kosztów związanych $\mathrm{z}$ dyscypliną rynkową $\mathrm{i}$ interwencjami nadzorczymi w sytuacji obniżenia się współczynnika wypłacalności do lub poniżej poziomu wymaganego przez nadzór bankowy [Lindquist 2003, s. 3].

Utrzymywanie większych nadwyżek współczynnika wypłacalności przez mniejsze banki o niższym poziomie funduszy własnych według Richardsona i Stephensona wynika $z$ tego, że działalność mniejszych banków jest mniej zdywersyfikowana, a więc bardziej narażona na ryzyko [Richardson, Stephenson 2000 , s. 44-45]. Uzasadnienie faktu, że duże banki utrzymują zwykle mniejszą nadwyżkę kapitału ponad obowiązujące normy niż banki mniejsze może też wynikać $\mathrm{z}$ ekonomii skali nadzorowania i monitorowania. Kontrolowanie kredytobiorców jest kosztowne i banki dążą do zrównania kosztów i przychodów wynikających z prowadzenia kontroli z kosztem pozyskania i utrzymywania nadwyżkowego kapitału. Dlatego duże banki odnosząc korzyści z ekonomii skali prowadzenia kontroli wykazują tendencję do utrzymywania mniejszych nadwyżek kapitału niż banki mniejsze. Kolejnym uzasadnieniem utrzymywania mniejszych nadwyżek kapitału przez duże banki jest hipoteza "too-big-to-fail". Duże banki, których upadek może zagrozić stabilności systemu bankowego, mogą pozwolić sobie na utrzymywanie mniejszych nadwyżek kapitałowych, gdyż w razie wystapienia kryzysu wysoce prawdopodobne jest otrzymanie przez nie pomocy ze strony państwa [Lindquist 2003, s. 3]. 


\section{Zależność pomiędzy współczynnikiem wypłacalności a wyposażeniem kapitałowym w bankach w Polsce - w skali sektora bankowego}

Przeanalizowano, czy w odniesieniu do banków działających w Polsce także występuje zależność pomiędzy wielkością banku a nadwyżką utrzymywanego kapitału, reprezentowana przez znacznie przekraczający obowiązujące unormowania poziom współczynnika wypłacalności. Na wykresie 1 przedstawiono wysokość funduszy własnych i współczynników wypłacalności poszczególnych banków w Polsce według stanu na koniec 2001 r. Zestawienie nie obejmuje wszystkich banków prowadzących wówczas działalność operacyjną, ale tylko te, dla których dysponowano odpowiednimi danymi (w zestawieniu ujęto banki, które dobrowolnie przekazały informacje finansowe do Encyklopedii banków 2002). Zestawienie nie obejmuje NBP, banków spółdzielczych, banków zrzeszających banki spółdzielcze oraz banków w stanie upadłości i likwidacji.

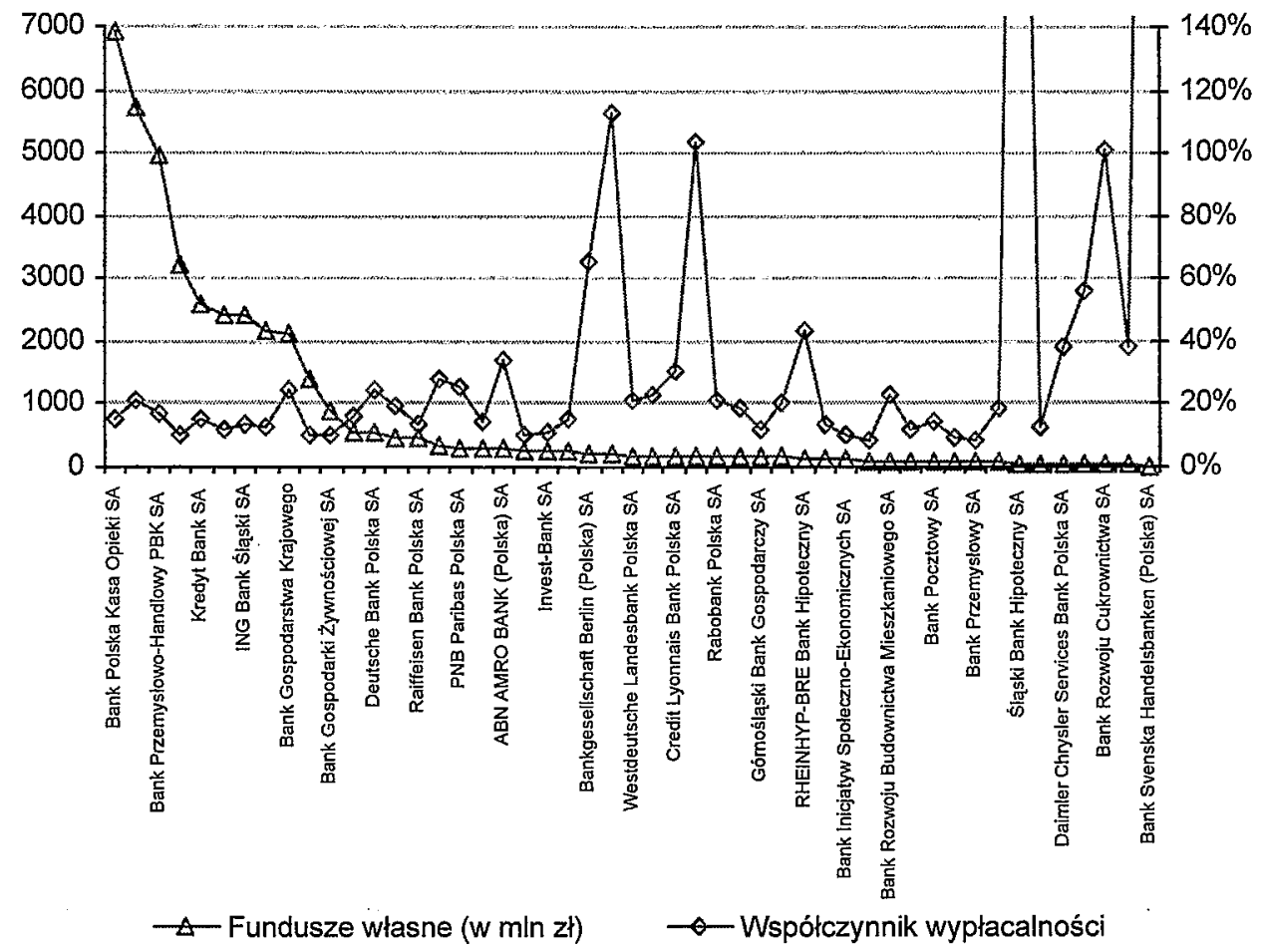

\section{Wykres 1}

Wysokość funduszy własnych i poziom współczynnika wypłacalności $w$ bankach w Polsce według stanu na koniec $2001 \mathrm{r}$.

Źródło: Opracowanie własne na podstawie: Encyklopedia banków 2002, s. 54-87 oraz Sytuacja finansowa banków w 2001 r., s. 55-57. 
W dużych bankach, w których poziom funduszy własnych przekraczał $1 \mathrm{mld}$ zł, współczynnik wypłacalności był utrzymywany na poziomie niewiele przekraczającym wymagane minimum. Współczynnik wypłacalności znacznie przekraczający wymagane $8 \%, 12 \%$ lub 15\% (w zależności od długości okresu działania banku) często występował w bankach mniejszych, o sumie funduszy własnych poniżej $250 \mathrm{mln} \mathrm{zl}$.

Nadzorcze wymogi kapitałowe obejmują zarówno wysokość współczynnika wypłacalności, jak i odpowiedni poziom funduszy własnych banku. Na wykresie 2 przedstawiono jednocześnie obie te wielkości dla banków komercyjnych w Polsce w latach 1993-2003.

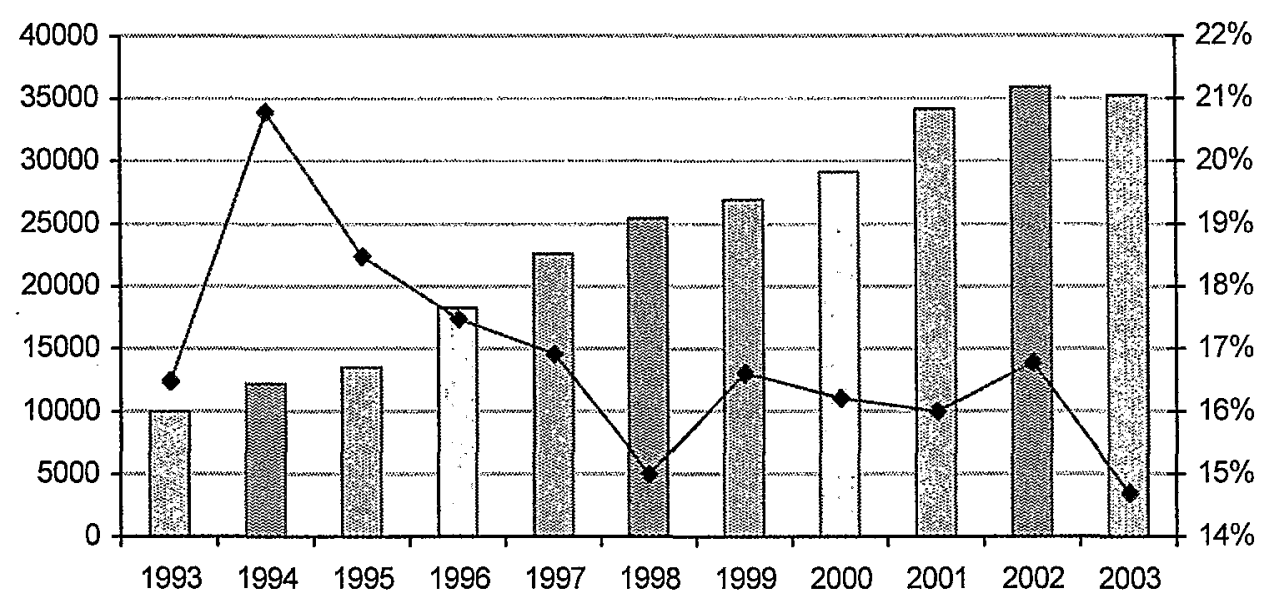

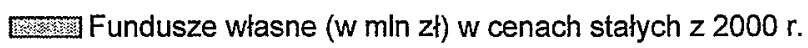

- Mediana współczynnika wypłacalności

\section{Wykres 2}

Wysokość funduszy własnych w cenach stalych i poziom współczynnika wypłacalności w bankach w Polsce

Źródło: Opracowanie własne na podstawie: Sytuacja finansowa banków w $2003 \mathrm{r}$., s. 60 oraz danych GUS.

W latach 1993-2002 realna wielkość funduszy własnych banków komercyjnych w Polsce zwiększała się, czemu towarzyszyło obniżanie się mediany współczynnika wypłacalności. W tym okresie zmniejszał się też udział banków o bardzo niskich i bardzo wysokich poziomach współczynnika wypłacalności. 


\section{Współczynnik wypłacalności i wyposażenie kapitałowe banków giełdowych w Polsce}

Według stanu na 30 czerwca 2004 r. lista banków giełdowych (banków, których akcje Komisja Papierów Wartościowych i Giełd dopuściła do publicznego obrotu) obejmowała następujące podmioty [Sytuacja finansowa banków w I półroczu 2004, s. 27-28]:

- Bank Handlowy w Warszawie S.A.,

- ING Bank Śląski S.A.,

- Bank Przemysłowo-Handlowy PBK S.A.,

- Bank Zachodni WBK S.A.,

- BRE Bank S.A.,

- Bank Millennium S.A.,

- Bank Polska Kasa Opieki S.A.,

- NORDEA BANK POLSKA S.A.,

- Kredyt Bank S.A.,

- Bank Ochrony Środowiska S.A.,

- FORTIS BANK POLSKA S.A.,

- DZ BANK Polska S.A.,

- Deutsche Bank PBC S.A.

Według stanu na koniec 2001 r., 8 spośród 13 analizowanych banków giełdowych było dużymi bankami, o sumie kapitałów własnych przekraczających $1 \mathrm{mld}$ zł. Dwa spośród analizowanych banków giełdowych posiadało kapitały własne na poziomie $500 \mathrm{mln}$ zł, a trzy poniżej $250 \mathrm{mln}$ zł. Najwyższym poziomem współczynnika wypłacalności charakteryzował się Deutsche Bank PBC S.A. (27,64\%), co i tak nie jest bardzo dużą wielkością w porównaniu ze współczynnikiem wypłacalności przekraczającym znacznie $100 \%$, jaki miały w tym samym czasie niektóre z banków nienotowanych na Warszawskiej Giełdzie Papierów Wartościowych, m.in. Bank Svenska Handelsbanken (Polska) S.A., Śląski Bank Hipoteczny S.A., czy Danske Bank Polska S.A. (patrz wykres 1).

Na wykresie 3 przedstawiono wysokość kapitałów własnych i poziom współczynnika wypłacalności banków giełdowych według stanu na koniec $2001 \mathrm{r}$.

Wszystkie banki giełdowe spełniały w 2001 r. zapisany w ustawie Prawo bankowe wymóg dotyczący utrzymywania funduszy własnych na poziomie nie niższym niż równowartość 5 mld $€$. W najmniejszym $z$ banków giełdowych, DZ BANK Polska S.A., poziom kapitałów własnych wynosił ok. 29,5 mld $€$.

Przeanalizowano też zmiany w czasie wysokości współczynnika wypłacalności i poziomu kapitałów własnych w 13 bankach giełdowych. Na wykresie 4 przedstawiono poziomy kapitału własnego w cenach stałych z 2000 r. i współczynników wypłacalności w latach 1994-2003 w tych bankach. 


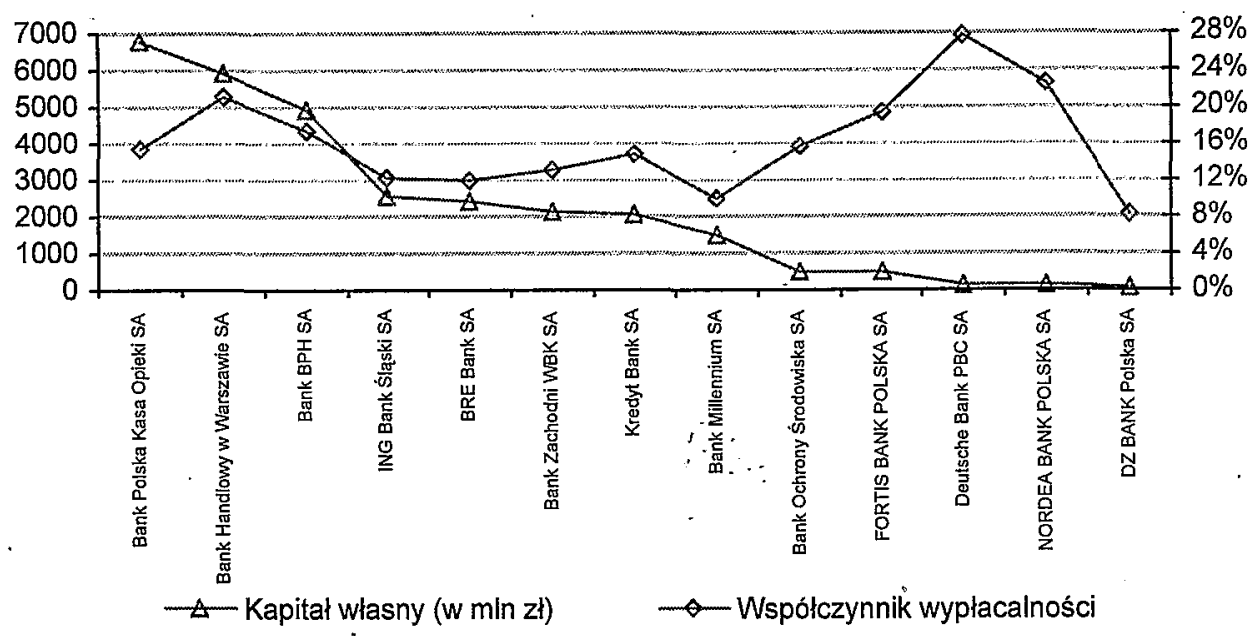

\section{Wykres 3}

Wielkość kapitałów własnych i poziom współczynnika wypłacalności banków giełdowych w Polsce według stanu na koniec $2001 \mathrm{r}$.

Źródło: Opracowanie własne na podstawie rocznych wyników finansowych poszczególnych banków giełdowych zamieszczonych na stronie internetowej http://www.parkiet.com/rap/rapwybor.jsp z 10.12.2004.

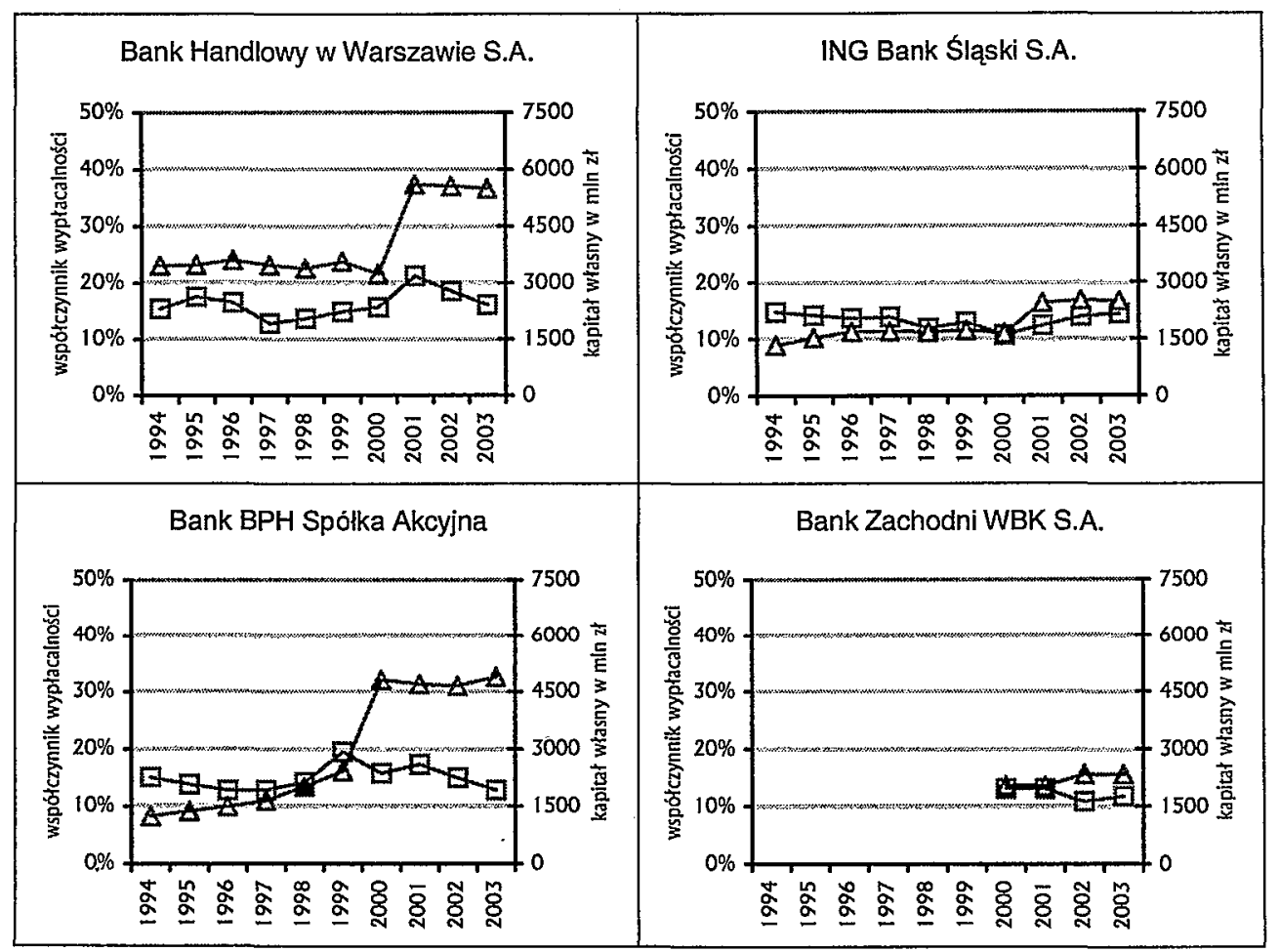




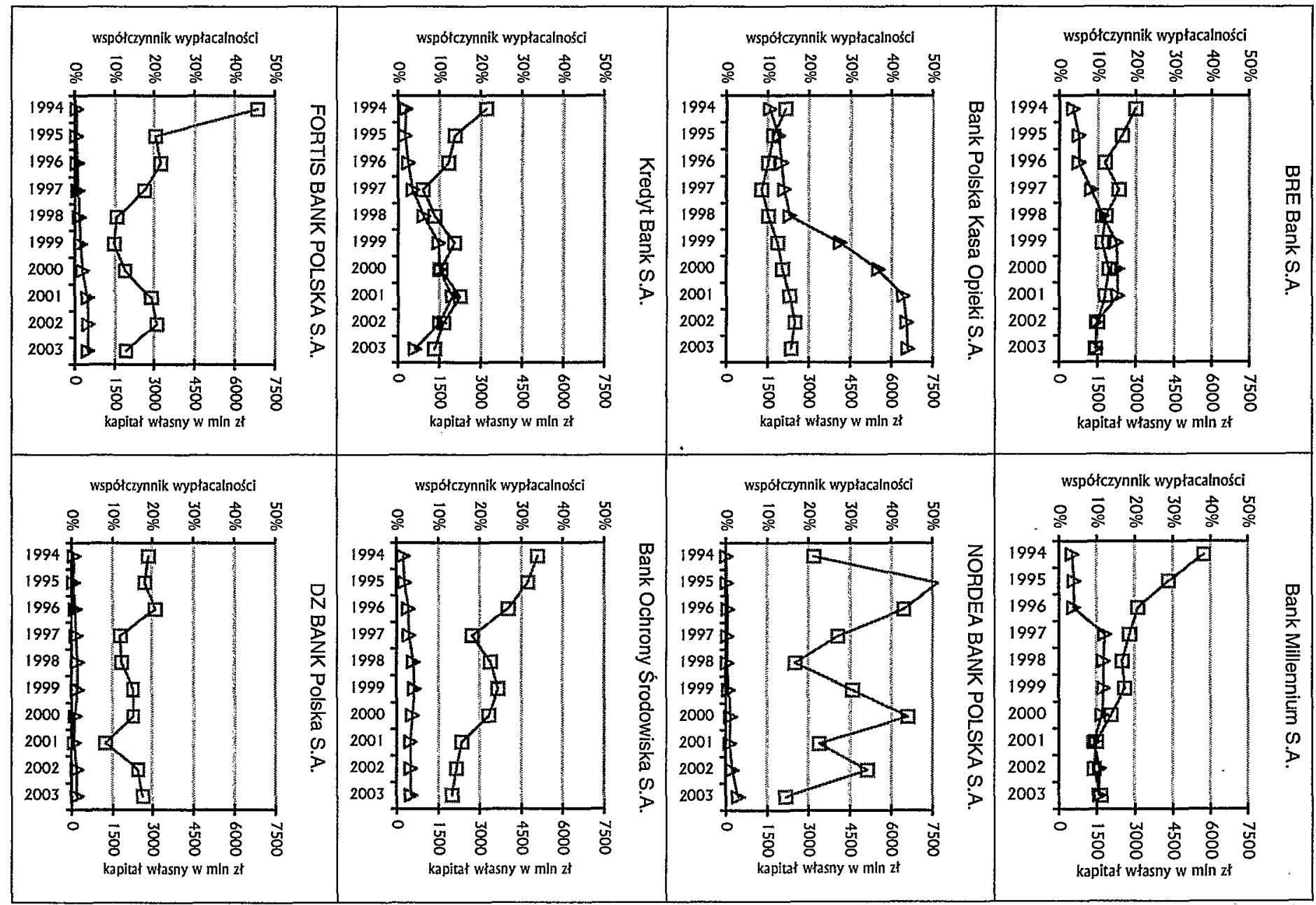




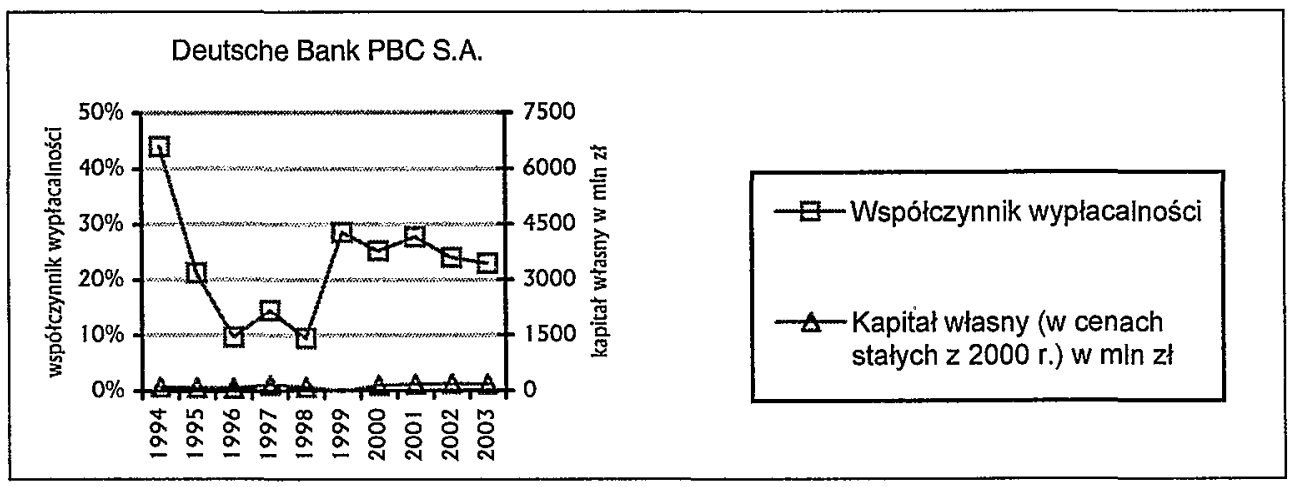

\section{Wykres 4}

Wysokość współczynników wypłacalności i wielkość kapitałów własnych w cenach stalych z 2000 r. w bankach giełdowych w Polsce w latach 1994-2003

Żródło: Opracowanie własne na podstawie rocznych wyników finansowych poszczególnych banków zamieszczonych na stronie internetowej http://www.parkiet.com/rap/rapwybor.jsp z 10.12.2004 i na podstawie raportów rocznych poszczególnych banków.

Wysoki poziom współczynnika wypłacalności, znacznie przekraczający wymagane $8 \%$, występował w bankach mniejszych, o niższych niż przeciętne wielkościach kapitałów własnych, a mianowicie w następujących bankach:

- Bank Millennium S.A. do 1996 r. (wtedy BIG S.A.),

- NORDEA BANK POLSKA S.A. (wcześniej Bank Komunalny S.A.),

- Bank Ochrony Środowiska S.A. do 2000 r.,

- FORTIS BANK POLSKA S.A. w 1994 r. (wtedy Pierwszy Polsko-Amerykański Bank S.A.),

- Deutsche Bank PBC S.A. (do 2000 r. Bank Współpracy Regionalnej S.A., następnie Deutsche Bank 24 S.A.).

Duże zmiany w wysokości kapitałów własnych pokrywały się w czasie z dużymi fuzjami i przejęciami. Sytuacja taka wystapiła w bankach:

- Bank Handlowy w Warszawie S.A. w 2001 r. na skutek połączenia z Citibank (Poland) S.A.,

- ING Bank Śląski S.A. w 2001 r. (wtedy Bank Śląski w Katowicach) na skutek dokapitalizowania przez ING,

- Bank BPH Spółka Akcyjna w 2000 r. (wtedy Bank Przemysłowo-Handlowy S.A.) na skutek dokapitalizowania przez Bayerische Hypo- und Vereinsbank AG oraz na skutek połączenia z Powszechnym Bankiem Kredytowym S.A., .

- Bank Millennium S.A. w 1997 r. (wówczas Bank Inicjatyw Gospodarczych BIG S.A.) na skutek połączenia z Bankiem Gdańskim S.A., 
- Bank Polska Kasa Opieki S.A. od 1999 r. na skutek dofinansowywania przez inwestora strategicznego - konsorcjum UniCredito Italiano SpA i Allians Aktiengesellschaft.

Na uwagę zasługuje też fakt, że Deutsche Bank PBC S.A. (wówczas Bank Współpracy Regionalnej S.A.) wykazał w 1999 r. ujemną wielkość kapitału własnego. Wynika to $\mathrm{z}$ faktu, że bank ten odnotował w tym roku bardzo wysoką stratę, znacznie przekraczającą kwotę posiadanych kapitałów własnych. Bank ten posiadał na koniec 1998 r. kapitał własny w wysokości ok. $77 \mathrm{mln}$ zł, ale poniesiona $\mathrm{w} 1999 \mathrm{r}$. strata $\mathrm{w}$ wysokości ok. 97,5 mln zl pomniejszyła kapitał własny banku, w rezultacie czego na koniec 1999 r. wykazywał on ujemną wartość kapitału własnego w kwocie ok. - 20,5 mln zł.

$\mathrm{Na}$ wykresie 5 zestawione zostały wielkości kapitałów własnych w cenach stałych i wysokości współczynnika wypłacalności w 13 analizowanych bankach giełdowych.

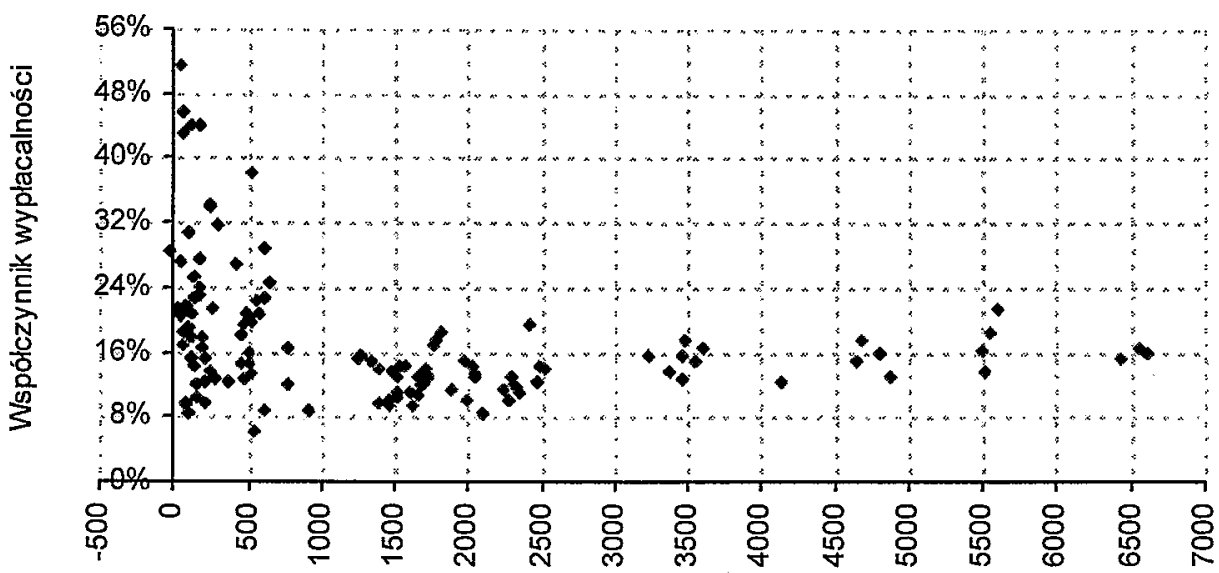

Kapitały w łasne $w$ mln zł w cenach stałych z $2000 \mathrm{r}$.

\section{Wykres 5}

Wysokość współczynników wypłacalności i wielkość kapitałów własnych w cenach stałych z 2000 r. w bankach giełdowych w Polsce w latach 1994-2003 Źródło: Opracowanie własne. Dane jak na wykresie 4.

Banki duże (jako kryterium przyjęto tu poziom kapitałów własnych powyżej $1 \mathrm{mld}$ zł) nie miały trudności z utrzymywaniem współczynnika wypłacalności na wymaganym poziomie $8 \%$. $Z$ drugiej strony unikały one utrzymywania znacznej nadwyżki współczynnika wypłacalności, która jest oznaką nieefektywnego działania banku (współczynnik wypłacalności tylko sporadycznie przekraczał 20\%). 
Inaczej jest $\mathrm{w}$ przypadku banków małych, wśród których zdarzały się przypadki niespełniania norm adekwatności kapitałowej. Małe banki znacznie częściej niż większe posiadały też znaczne nadwyżki kapitału w stosunku do realizowanej akcji kredytowej.

Średnia wysokość współczynnika wypłacalności w grupie banków małych (o kapitałach własnych w cenach stałych z 2000 r. poniżej 1 mld zł) wynosiła $21,11 \%$, podczas gdy w bankach dużych (o kapitałach własnych w cenach stałych z 2000 r. powyżej 1 mld zl) 13,73\%. Mediana współczynnika wypłacalności wynosiła odpowiednio: 19,55\% w bankach małych i 13,66\% w bankach dużych. Banki z tych dwóch grup różniły się także pod względem wariancji współczynnika wypłacalności. Większą zmiennością współczynnika wypłacalności charakteryzowały się mniejsze banki. W bankach dużych wariancja wynosiła $0,07 \%$, podczas gdy w bankach małych $1,03 \%$.

\section{Podsumowanie}

$\mathrm{Na}$ podstawie przedstawionych w pracy danych można stwierdzić, że w skali sektora bankowego obniżaniu się współczynnika wypłacalności towarzyszył realny wzrost funduszy własnych. Zauważono też, że największe banki utrzymywały współczynnik wypłacalności na poziomie niewiele przekraczającym obowiąujące unormowania, podczas gdy w mniejszych bankach występowały zarówno bardzo wysokie, jak i bardzo niskie poziomy współczynnika wypłacalności. Niskie wartości współczynnika wypłacalności w małych bankach moga być symptomem trudności $\mathrm{z}$ utrzymaniem wypłacalności banku. Znacznie przewyższające minimalne wymogi wysokości współczynnika wypłacalności są z kolei objawem nieefektywnego gospodarowania kapitałem przez bank. Bank posiadający duże nadwyżki kapitału mógłby przeznaczyć je na zwiększenie akcji kredytowej, a zatem na wzrost dochodów. Z punktu widzenia wyposażenia kapitałowego i współczynnika wypłacalności duże banki cechują się wyższą efektywnością działania niż banki mniejsze.

\section{Literatura}

BIEŃ W., SOKÓŁ H.: Ocena sytuacji finansowej banku komercyjnego, Difin, Warszawa 2000.

Encyklopedia banków, „Bank. Miesięcznik Finansowy” nr 6/2002.

LINDQUIST K.: Banks' buffer capital: How important is risk?, Norges Bank, Oslo 2003. 
Raport o stabilności systemu finansowego - czerwiec 2001 - grudzień 2002, NBP, Warszawa 2003.

RICHARDSON J.: STEPHENSON M., Some aspects of regulatory capital, FSA Occasional Paper, Londyn 2000.

Sytuacja finansowa banków w $2001 \mathrm{r}$. Synteza, GINB, Warszawa 2002.

Sytuacja finansowa banków w 2003 r. Synteza, GINB, Warszawa 2004.

Sytuacja finansowa banków w I półroczu 2004 r. Synteza, GINB, Warszawa 2004.

ZALESKA M.: Wpływ wybranych regulacji zewnętrznych na działalność polskich banków, Monografie i Opracowania SGH, Warszawa 1999.

\title{
The Impact of the Amount of Bank's Capital on the Solvency Ratio
}

\begin{abstract}
In the paper connections between bank's capital and solvency ratio were analyzed. Level of solvency ratio and capital in Polish banking sector and banks participating in Warsaw Stock Exchange were compared. It has been stated that the smaller the bank was the higher or more varying buffer capital was.
\end{abstract}

